\title{
PENGARUH PENERAPAN e-SPT TERHADAP EFISIENSI \\ PEMROSESAN DATA PERPAJAKAN \\ (Survey Terhadap Pengusaha Kena Pajak pada KPP Pratama Kota Tomohon) \\ E-SPT EFFECT OFAPPLICATIONOFEFFICIENCYTAXDATAPROCESSING \\ (Survey AgainstTaxable Personon STOTomohon)
}

\author{
Oleh : \\ Debbie Deborah. S. Mokolinug ${ }^{1}$ \\ Novi S. Budiarso ${ }^{2}$ \\ ${ }^{1,2}$ FakultasEkonomidanBisnis, JurusanAkuntansi \\ Universitas Sam Ratulangi \\ email :1debbiemoko@gmail.com \\ ²novi.sbudiarso@yahoo.com
}

\begin{abstract}
Abstrak: Berbagai terobosan yang terkait dengan aplikasi Teknologi Informatika dalam kegiatan perpajakan pun terus dilakukan guna memudahkan, meningkatkan serta mengoptimalisasikan pelayanan kepada Wajib Pajak. Ada banyak faktor yang mempengaruhi kesuksesan teknologi informasi yang diterapkan. Hal tersebut terkait dengan penelitian ini yang juga menganalisis kesuksesan teknologi informasi yang dibentuk oleh Direktorat Jendral Pajak (DJP) yaitu $e$-SPT. Penelitian ini dilakukan untuk memverifikasi kesuksesan sistem eSPT yang digunakan oleh pengusaha kena pajak. Tujuan penelitian ini adalah untuk mengetahui pengaruh kepraktisan, kemudahan perhitungan, kemudahan pelaporan dan keandalan e-SPT terhadap efisiensi pemrosesan data perpajakan.Metode analisis yang digunakan adalah analisa regresi berganda. Hasil penelitian menunjukan bahwa kepraktisan dan kemudahan perhitungan berpengaruh secara signifikan terhadap efisiensi pemrosesan data perpajakan pada pengusaha kena di Kota Tomohon sedangkan kemudahan pelaporan dan kepraktisan e-SPT tidak berpengaruh secara signifikan terhadap efisiensi pemrosesan data perpajakan pada pengusaha kena di Kota Tomohon.
\end{abstract}

Kata Kunci: kepraktisan, kemudahan perhitungan, kemudahan pelaporan keandalan, e-SPT, efisiensi pemrosesan data dan perpajakan

\begin{abstract}
Breakthroughs related to the application of Information Technology in taxation activity continues to be done in order to facilitate, improve and optimize the service to taxpayers. There are many factors that influence the success of applied information technology. It is associated with a recent study also analyzes the success of information technology established by the Directorate General of Taxation (DGT) is an e-SPT This study was conducted to verify the success of e-SPT system used by employers taxable. The purpose of this study was to determine the effect of practicality, ease of calculation, the ease of reporting and reliability of e-tax return on tax data processing efficiency. The analytical method used is multiple regression analysis. The results showed that the practicality and ease of calculation significantly affect the efficiency of data processing tax on taxable employers in Tomohon while reporting the ease and convenience of e-SPT does not significantly affect the efficiency of data processing tax on taxable employers in Tomohon
\end{abstract}

Keywords: practicality, ease of calculation, the ease of reporting reliability, e-SPT, the efficiency of data processing and taxation 


\section{LatarBelakang}

\section{PENDAHULUAN}

Modernisasi administrasi perpajakan dilakukan oleh DJP sebagai bentuk peningkatan kualitas pelayanan perpajakan terhadap wajib pajak salah satunya dikembangkannya pelaporan pajak terutang dengan menggunakan elektronik SPT (e-SPT).Pelaporan pajak terutang melalui SPT manual dinilai masih memiliki kelemahan khususnya bagi wajib pajak yang melakukan transaksi cukup besar harus melampirkan dokumen (hardcopy) dalam jumlah cukup besar kepada Kantor Pelayanan Pajak (KPP), sementara proses perekaman data memakan waktu cukup lama sehingga pelaporan SPT menjadi tertunda dan terlambat serta menyebabkan denda. Selain itu dapat terjadi kesalahan (human error) dalam proses ulang perekaman data secara manual oleh fiskus. Sementara itu pelaporan menggunakan e-SPT lebih dinilai lebih efisien tetapi, kurangnya pemahaman wajib pajak mengenai sistem pelaporan digital (e SPT) menyebabkan masih banyaknya wajib pajak yang tidak mau menggunakan e-SPT dan lebih memilih menggunakan SPT manual, padahal penggunaan e-SPT mengurangi terjadinya penumpukan data yang harus direkam oleh Kantor Pelayanan Pajak. Selain itu penggunaan e-SPT pada dasarnya membantu wajib pajak dalam menyampaikan SPT lebih cepat, aman dan efisien karena lampiran dalam bentuk $C D /$ flash disk.

Penting untuk mengetahui bagaimana persepsi para Wajib Pajak mengenai penerapan aplikasi e-SPT karena secara tidak langsung berkaitan dengan kepercayaan dan dukungan masyarakat terhadap niat baik pemerintah untuk menyelenggarakan penghimpunan dan pemanfaatan dana hasil pajak secara jujur, transparan dan adil. Apabila persepsi wajib pajak mengenai penerapan e-SPT selama ini dianggap telah membantu dalam pemrosesan data perpajakan maka dapat dikatakan bahwa penerapan e-SPT berpengaruh terhadap efisiensi pemrosesan data perpajakan.

Agar target penerimaan pajak tercapai harus didukung oleh fasilitas-fasilitas pajak dan kepatuhan wajib pajak dalam membayar kewajibannnya. Salah satu fasilitas pajak dalam rangka modernisasi administrasi perpajakan adalah e-SPT yang merupakan aplikasi (software) yang dibuat oleh DJP untuk digunakan oleh wajib pajak untuk kemudahan dalam penyampaian SPT. Penggunaan e-SPT dimaksudkanagar semua proses kerja dan pelayanan perpajakan berjalan dengan baik, lancar, akurat serta mempermudah wajib pajak dalam melaksanakan kewajiban perpajakannya sehingga kepatuhan wajib pajak diharapkan akan meningkat

Pemrosesan data perpajakan merupakan salah satu fasilitas pajak dalam rangka modernisasi administrasi perpajakan yang dibuat oleh DJP untuk digunakan oleh wajib pajak untuk kemudahan dalam penyampaian SPT agar semua proses kerja dan pelayanan perpajakan berjalan dengan baik, lancar, akurat serta mempermudah wajib pajak dalam melaksanakan kewajiban perpajakannya sehingga kepatuhan wajib pajak diharapkan akan meningkat.

Dalam penelitian ini peneliti memfokuskan pada Badan/Pengusaha Kena Pajak (PKP) mengingat PKP yang dalam satu masa pajak melakukan transaksi lebih dari 25 transaksi diwajibkan untuk menggunakan e-SPT sebagaimana tercantum dalam PER-45/PJ/2010 tentang bentuk, isi dan tata cara pengisian serta penyampaian SPT Masa PPN bagi Pengusaha Kena Pajak (PKP) yang menggunakan pedoman penghitungan pengkreditan pajak masukan yang menerbitkan nota retur atau nota pembatalan dengan jumlah lebih dari 25 dokumen dalam 1 masa pajak, diwajibkan menggunakan e-SPT sesuai dengan PER-45/PJ/2010. Penggunaan e-SPT diharapkan dapat mengurangi kesalahan dalam pemasukan (input) data dan mempercepat pembentukan database pajak keluaran dan pajak masukan sehingga dapat dijadikan bahan referensi (optimalisasi pemanfaatan data pajak).

Berbagai terobosan yang terkait dengan aplikasi Teknologi Informatika dalam kegiatan perpajakan pun terus dilakukan guna memudahkan, meningkatkan serta mengoptimalisasikan pelayanan kepada Wajib Pajak. Ada banyak faktor yang mempengaruhi kesuksesan teknologi informasi yang diterapkan.Hal tersebut terkait dengan penelitian ini yang juga menganalisis kesuksesan teknologi informasi yang dibentuk oleh Direktorat Jendral Pajak (DJP) yaitu $e$-SPT Penelitian ini dilakukan untuk memverifikasi kesuksesan sistem e-SPT yang digunakan oleh pengusaha kena pajak.

\section{Tujuan Penelitian}

1. Untuk mengetahui pengaruh kepraktisan e-SPT terhadap efisiensi pemrosesan data perpajakan.

2. Untuk mengetahui pengaruh kemudahan perhitungan e-SPT terhadap efisiensi pemrosesan data perpajakan.

3. Untuk mengetahui pengaruh kemudahan pelaporan e-SPT berpengaruh terhadapefisiensi pemrosesan data perpajakan.

4. Untuk mengetahui pengaruh keandalan e-SPT terhadap efisiensi pemrosesan data perpajakan. 


\section{KonsepAkuntansi}

\section{TINJAUAN PUSTAKA}

Simamora (2013:1) mendefinisikan akuntansi sebagai seni untuk mengumpulkan, mengklasifikasikan, mencatat dan menghasilkan laporan, yaitu laporan keuangan yang dapat digunakan oleh pihak-pihak yang berkepentingan (stakeholders) baik pihak di dalam perusahaan ataupun pihak di luar perusahaan.

\section{AkuntansiPajak}

Simamora (2013:35) mendefinisikan akuntansi pajak adalah akuntansi yang berkaitan dengan perhitungan perpajakan dan mengacu pada peraturan dan perundang-undangan perpajakan beserta aturan pelaksanaannya.

\section{Pajak}

Bohari (2006:23-24) mendefiniskan pajak adalah prestasi pemerintah yang terhutang melalui norma-norma umum yang dapat dipaksakan tanpa adanya kontra prestasi yang dapat ditunjukkan.

\section{Wajib Pajak}

Wajib pajak menurut undang-undang No. 16 Tahun 2000 tentang ketentuan umum dan tata cara perpajakan (selanjutnya ditulis dengan singkatan Undang-Undang KUP) pasal 1 ayat (1) adalah orang pribadi atau badan yang menurut ketentuan peraturan perundang-undangan perpajakan ditentukan untuk melakukan kewajiban perpajakan, termasuk pemungutan pajak atau pemotongan pajak tertentu.

\section{Surat Pemberitahuan (SPT)}

Surat Pemberitahuan (SPT) menurut undang-undang No.16 tahun 2009 mengenai KUP Pasal 1 angka 11 dan Peraturan Menteri Keuangan Nomor 152/PMK.03/2009 adalah surat yang oleh wajib pajak digunakan untuk melaporkan penghitungan dan/atau pembayaran pajak, objek pajak dan/atau bukan objek pajak, dan/atau harta dan kewajiban sesuai dengan ketentuan peraturan perundang-undangan perpajakan.

\section{Fungsi SPT}

Fungsi SPT dapat dilihat dari sisi Wajib Pajak, Pengusaha Kena Pajak, dan dari sisi Pemotong atau Pemungut Pajak (Lingga, 2012 : 37), yaitu sebagai berikut:

\section{Wajib Pajak Penghasilan}

a. Sarana untuk melapor dan mempertanggungjawabkan perhitungan pajak yang sebenarnya terutang.

b. Melapor pembayaran/pelunasan pajak yang telah dilaksanakan sendiri dan/atau melalui pemotongan/pemungutan pihak lain dalam satu tahun pajak/bagian tahun pajak.

c. Melaporkan pembayaran dari pemotong/pemungut tentang pemotongan/ pemungutan pajak orang pribadi atau badan lain dalam satu masa pajak, sesuai dengan peraturan perudang-undangan yang berlaku.

2. Pengusaha Kena Pajak

a. Sarana untuk melapor dan mempertanggungjawabkan perhitungan jumlah Pajak Pertambahan Nilai (PPN) dan Pajak Penjualan atas Barang Mewah (PPnBM) yang sebenarnya terutang.

b. Melaporkan tentang pengkreditan Pajak Masukan terhadap Pajak Keluaran

c. Melaporkan tentang pembayaran/pelunasan pajak yang telah dilaksanakan sendiri oleh PKP dan/atau melalui pihak lain dalam satu masa pajak, sesuai dengan ketentuan peraturan perundang-undangan perpajakan.

\section{Pemotong/Pemungut Pajak}

Sebagai sarana melapor dan mempertanggungjawabkan pajak yang dipotong/ dipungut dan disetorkannya.

\section{Jenis SPT}

SPT dapat berbentuk formulir kertas (hardcopy) atau e-SPT. Berdasarkan waktu pelaporan, SPT dibedakan menjadi dua (Lingga, 2012:47) yaitu:

1. SPT Masa adalah surat yang oleh wajib pajak digunakan untuk melaporkan perhitungan dan/atau pembayaran pajak yang terutang dalam suatu masa pajak.

2. SPT Tahunan adalah surat yang oleh wajib pajak digunakan untuk melaporkan perhitungan dan/atau pembayaran pajak yang terutang dalam suatu tahun pajak. 


\section{Surat Pemberitahuan Elektronik (e-SPT)}

Pandiangan, Liberti (2008:35) menyatakan e-SPT adalah penyampaian SPT dalam bentuk digital ke KPP secara elektronik atau dengan menggunakan media komputer, sedangkan pengertian e-SPT menurut DJP adalah Surat Pemberitahuan beserta lampiran-lampirannya dalam bentuk digital dan dilaporkan secara elektronik atau dengan menggunakan media komputer yang digunakan untuk membantu wajib pajak dalam melaporkan perhitungan dan pembayaran pajak yang terutang sesuai dengan ketentuan peraturan perundangundangan yang berlaku.

\section{Tata Cara Pelaporan e-SPT}

Tata cara pelaporan e-SPT adalah sebagai berikut:

1. Wajib pajak melakukan instalasi aplikasi e-SPT pada sistem komputer yang digunakan untuk keperluan administrasi perpajakannya.

2. Wajib pajak menggunakan aplikasi e-SPT untuk merekam data-data perpajakan yang akan dilaporkan, antara lain:

a. Data identitas wajib pajak pemotong/pemungut dan identitas wajib pajak yang dipotong/dipungut seperti NPWP, nama, alamat, kode pos, nama KPP, pejabat penandatangan, kota, format nomor bukti potong/pungut, nomor awal bukti potong/pungut, kode kurs mata uang yang digunakan.

b. Bukti pemotongan/pemungutan $\mathrm{PPh}$.

c. Faktur Pajak

d. Data perpajakan yang terkandung dalam SPT.

e. Data Surat Setoran Pajak (SSP) seperti masa pajak, tahun pajak, tanggal setor, Nomor Transaksi Penerimaan Negara (NTPN), Kode Akun Pajak/Kode Jenis Setoran (KJS) dan jumlah pembayaran pajak.

3. Wajib pajak yang telah memiliki sistem administrasi keuangan/perpajakan sendiri dapat melakukan proses impor data dari sistem yang dimiliki wajib pajak kedalam aplikasi e-SPT dengan mengacu kepada format data yang sesuai dengan aplikasi e-SPT.

4. Wajib pajak mencetak bukti potong/pungut dengan menggunakan aplikasi e-SPT dan menyampaikannya kepada pihak yang dipotong/dipungut.

5. Wajib pajak menandatangani SPT Masa PPh/PPN dan/atau SPT Tahunan PPh hasil cetakan aplikasi e-SPT.

6. Wajib pajak menandatangani SPT Masa PPh/PPN dan/atau SPT Tahunan PPh hasil cetakan aplikasi e-SPT.

7. Wajib pajak membentuk file data SPT dengan menggunakan aplikasi e-SPT dan disimpan dalam media elektronik (CD, flash disk).

8. Wajib pajak menyampaikan e-SPT ke KPP tempat wajib terdaftar dengan cara:

a. Secara langsung atau melalui pos/perusahaan jasa kurir ekspedisi/kurir dengan bukti pengiriman surat, dengan membawa atau mengirimkan formulir induk SPT Masa PPh dan/atau SPT Masa PPN dan/atau SPT Tahunan PPh hasil cetakan e-SPT yang telah ditandatangani dan file data SPT yang tersimpan dalam bentuk elektronik serta dokumen lain yang wajib dilampirkan; atau

b. Melalui e-filling sesuai dengan ketentuan yang berlaku.

9. a. Atas penyampaian e-SPT secara langsung diberikan tanda penerimaan surat dari TPT sedangkan penyampaian e-SPT melalui pos atau jasa ekspedisi/kurir bukti pengiriman surat dianggap sebagai tanda terima SPT.

b. Atas penyampaian melalui $e$-filling diberikan bukti penerimaan elektronik.

\section{Hipotesis}

$\mathrm{H}_{1}:$ Kepraktisan e-SPT berpengaruh terhadap efisiensi pemrosesan data perpajakan

$\mathrm{H}_{2}$ : Kemudahan perhitungan e-SPT berpengaruh terhadapefisiensi pemrosesan data perpajakan

$\mathrm{H}_{3}$ : Kemudahan pelaporan e-SPT berpengaruh terhadapefisiensi pemrosesan data perpajakan

$\mathrm{H}_{4}$ : Keandalan e-SPT berpengaruh terhadapefisiensi pemrosesan data perpajakan

\section{Penelitian Terdahulu}

1. Lingga (2012) menelititentangPengaruh Penerapan e-SPT Terhadap Efisiensi Pemrosesan Data Perpajakan: Survey Terhadap Pengusaha Kena Pajak pada KPP Pratama X, Bandung. Kesimpulandaripenelitiantersebutadalah penerapan e-SPT berpengaruh terhadap efisiensi pemrosesan data 
perpajakan. Efisiensi pemrosesan data perpajakan dipengaruhi oleh penerapan e-SPT sebesar 36,4\%, sisanya 63,6\% dipengaruhi oleh faktor-faktor lain yang tidak diamati dalam penelitian ini. PersamaandenganpenelitianpenulisadalahPenggunaan Variabel independen dan variabel dependen, sedangkanperbedaanyaterletakpadaobjekpenelitian.

2. Tamboto (2013)menelititentangPengaruh Penerapan e-SPT PPN Terhadap Efisiensi Pengisian SPT PPN Menurut Persepsi Pengusaha Kena Pajak pada KPP Pratama Manado. Kesimpulandaripenelitiantersebutadalahpenerapan e-SPT PPN berpengaruh terhadap efisiensi pengisian SPT menurut persepsi pengusaha kena pajak pada Kantor Pelayanan Pajak Pratama Manado.Persamaandenganpenelitianpenulisadalahpenempatanvariabel independen serta alat analisissedangkanperbedaanyaterletakpadaobjekpenelitian.

\section{METODE PENELITIAN}

\section{JenisPenelitian}

Penelitian ini merupakan penelitian asosiatif. Menurut Sugiyono (2010:100) penelitian asosiatif merupakan penelitian yang bertujuan untuk mengetahui pengaruh dua variabel atau lebih.

\section{TempatdanWaktuPenelitian}

Penelitian ini dilakukan di Kota Tomohon dengan objek penelitian yaitu wajib pajak badan/pengusaha kena pajak di Kota Tomohon. Tempat Penelitian adalah Kantor Pelayanan Penyuluhandan Konsultan Perpajakan (KP2KP) Tomohon yang bertempat di J1 Raya Manado - Tomohon, Kakaskasen III. Periode waktu penelitian dimulai dari awal Desember 2014.

\section{ProsedurPenelitian}

Prosedur penelitian yang dilakukan penulis adalah

1. Melakukan kajian awal dengan melakukan studi literatur baik studi kepustakaan maupun membaca melalui internet.

2. Melakukan pengidentifikasian tentang masalah

3. Merumuskannya

4. Menetapkan tujuan/ manfaat penelitian

5. Membatasi masalah ke lingkup yang disesuaikan dengan penelitian saat ini.

\section{Populasi dan Sampel}

Populasi dalam pelaksanaan penelitian ini merupakan seluruh karakteristik yang berhubungan dengan penelitian, dalam hal ini wajib pajak badan/pengusaha di kota Tomohon yang terdaftar di KPP Pratama Tomohon tahun 2014 sebanyak 199 badan usaha kena pajak dan kusioner yang dibagikan sebanyak 90 eksemplar kepada badan usaha/pengusaha kena pajak. Sampel dalam penelitian ini ditetapkan sebanyak 60 responden sesuai dengan jumlah kusioner yang dikembalikan dengan metode pengambilan sampel adalah metode purposive sampling atau sampel dipilih secara sengaja.

Adapun klasifikasi jumlah sampel dalam penelitian ini dapat dilihat dalam tabel 3.1. sebagai berikut :

\section{MetodePengumpulan Data}

Jenis data dapat dibedakan menjadi dua jenis (Kuncoro 2006: 24) yaitu :

1. Data kualitatif merupakan data yang tidak dapat diukur dalam skala numerik atau data yang disajikan secara deskriptif atau yang berbentuk uraian

2. Data kuantitatif merupakan data yang disajikan dalam bentuk skala numerik (angka-angka), namun dalam statistik semua data harus dalam bentuk angka, maka data kualitatif umumnya dikuantitatifkan agar dapat diproses

Jenis data yang digunakan dalam penelitian ini berupa data kualitatif yang di kuantitatifkan dengan skala likert. Dimana data tersebut berupa Penerapan e-SPT Terhadap Efisiensi Pemrosesan Data Perpajakan pada Pengusaha Kena Pajak pada KPP Pratama Kota Tomohondiukur dengan menggunakan kuesiner berskala likert Sumber data yang digunakan dalam penelitian, yaitu sebagai berikut:

1. Data primer adalah data yang diperoleh langsung dari badan/pengusaha kena pajak yang di terdaftar di KPP Pratama Tomohon dengan cara memberikan kuisioner 
2. Data sekunder adalah data yang telah dikumpulkan oleh lembaga pengumpul data dan dipublikasikan kepada masyarakat pengguna data (Kuncoro, 2006:137)

Data yang dibutuhkan dalam penelitian ini dikumpulkan melalui metode penelitian lapangan (field Research method) yaitu pengumpulan data dengan mengadakan penelitian degan cara:

1. Observasi yaitu teknik pengumpulan data dengan cara melakukan pengamatan langsung terhadap objek penelitian.

2. Kuesioner yaitu merupakan daftar yang diberikan pertanyaan-pertanyaan yang berhubungan dengan pemasalahan yang akan diteliti. Kuesioner ini dibagikan kepada pengusaha/badan kena pajak di kota Tomohon

3. Wawancara yaitu teknik pengumpulan data dengan mengadakan tanya jawab secara langsung dengan pengusaha/badan kena pajak di kota Tomohon.

\section{MetodeAnalisis}

Metode analisis yang digunakan adalahanalisisregresi linear berganda.

\section{Definisi Operasional}

1. e-SPT adalah SPT dalam bentuk digital ke KPP secara elektronik atau dengan menggunakan media komputer

2. Pengisian e-SPT PPN adalah pengisian aplikasi e-SPT untuk merekam data-data perpajakan yang akan dilaporkan.

3. Pengusaha kena pajak adalah pengusaha yang menurut ketentuan peraturan perundang-undangan perpajakan ditentukan untuk melakukan kewajiban perpajakan, termasuk pemungutan pajak atau pemotongan pajak tertentu

- Variabel Penerapan e-SPT PPN

Terdiri dari

a. Kepraktisan (X1)

b. Kemudahan Perhitungan (X2)

c. Kemudahan pelaporan (X3)

d. Keandalan (X4)

- Variabel efisiensi pemrosesan data perpajakan: (Y)

\section{HASIL PENELITIAN DAN PEMBAHASAN}

\section{Deskripsi Objek Penelitian}

Kantor Pelayanan Pajak Pratama Manado Merupakan Instansi Vertikal Direktorat Jendral Pajak di bawah Kantor Wilaya DJP Sulawesi Bagian Utara Tengah Gorontalo dan Maluku Utara yang bernaung di bawah Departemen Keuangan Repoblik Indonesia.Tugas dari Kantor Pelayanan Pajak Pratama Manado adalah malaksanakan tugas Pokok Direktorat Jendral Pajak dalam penerimaan Negara.

\section{Hasil Penelitian}

Untuk mengukur pengaruh antara variabel bebas (X) terhadap variabel terikat $(\mathrm{Y})$, dalam hal ini mengukur pengaruh kepraktisan, kemudahan perhitungan, kemudahan pelaporan dan keandalan e-SPT berpengaruh terhadap efisiensipemrosesan data perpajakanpadapengusahakenapajak di KPP Kota Tomohon dapat dilhat dalam tabel berikut ini:

Tabel 1Hasil Analisis Regresi Linear Berganda

\begin{tabular}{lclll}
\hline $\begin{array}{l}\text { Variabel } \\
\text { Constant) }\end{array}$ & B & t Hitung & Sig & Keterangan \\
\hline Kepraktisan $\left(\mathrm{X}_{1}\right)$ & 4.315 & & & \\
Kemudahanperhitungan(X2) & 0,342 & 2.824 & 0,007 & Signifikan \\
Kemudahan pelaporan (X3) & 0.429 & 3.863 & 0.001 & Signifikan \\
Keandalan e-SPT (X4) & 0.105 & 1.137 & 0.260 & Tidak Signifikan \\
Koefisien & 0.029 & 0.278 & 0.782 & Tidak signifikan \\
R & & Hasil & Uji F & Hasil \\
R Square $\left(\mathrm{R}^{2}\right)$ & & 0,913 & F hitung & 68.779 \\
& & 0,883 & &
\end{tabular}


Persamaan regresi berganda dalam penelitian ini dapat ditulis sebagai berikut:

$\mathrm{Y}=4.315+0.342 \mathrm{X}_{1}+0.429 \mathrm{X}_{2}+0.105 \mathrm{X}_{3}+0.029 \mathrm{X}_{4}$

Interprestasi dari persamaan diatas adalah sebagai berikut :

a. $\alpha=4.315$, nilai konstanta ini menunjukan apabila kepraktisan, kemudahan perhitungan, kemudahan pelaporan dan keandalane-SPT sama dengan 0 , maka efisiensi pemrosesan data perpajakan pada pengusaha kena di Kota Tomohona dalah sebesar 4.315

b. $\mathrm{B}_{1}=+0.342$, koefisien regresi ini menunjukan bahwa kepraktisan e-SPT naik $1 \%$ maka akan meningkatkan efisiensi pemrosesan data perpajakan pada pengusaha kena di Kota Tomohon $0.342 \%$ dengan asumsivariabel lainnya tetap atau sama dengan nol.

c. $\mathrm{B}_{2}=+0.429$, koefisien regresi ini menunjukan bahwa kemudahan perhitungan naik $1 \%$ maka akan meningkatkan efisiensi pemrosesan data perpajakan pada pengusaha kena di Kota Tomohon senilai $0.429 \%$ dengan asumsi variabel lainnya tetap atau sama dengan nol.

d. $B_{3}=+0.105$, koefisien regresi ini menunjukan bahwa kemudahan pelaporan naik $1 \%$ maka akan meningkatkan efisiensi pemrosesan data perpajakan pada pengusaha kena di Kota Tomohon senilai $0.105 \%$ dengan asumsi variabel lainnya tetap atau sama dengan nol.

e. $B_{4}=+0.029$, koefisien regresi ini menunjukan bahwa keandalan e-SPT naik $1 \%$ maka akan meningkatkan efisiensi pemrosesan data perpajakan pada pengusaha kena di Kota Tomohon senilai $0.029 \%$ dengan asumsi variabel lainnya tetap atau sama dengan nol.

Uji t digunakan untuk mengetahui apakah masing - masing variabel independen, yaitu kepraktisan, kemudahan perhitungan, kemudahan pelaporan dan keandalan e-SPT berpengaruh terhadap efisiensi pemrosesan data perpajakan. .

Kepraktisan mempunyai nilai signifkasi 0.007 yang berarti nilai ini lebih kecil dari 0.05 , dengan t hitung 2.826> t tabel 2.000, maka $\mathrm{H}_{\mathrm{a}}$ diterima dan $\mathrm{H}_{\mathrm{o}}$ ditolak. Dengan demikian disimpulkan bahwa secara parsial kepraktisan berpengaruh terhadap efisiensi pemrosesan data perpajakan pada pengusaha kena di Kota Tomohon.

Kemudahan perhitunganmempunyai nilai signifkasi 0,001 yang berarti nilai ini lebih kecil dari 0.05 dengan t hitung $3.683>2.000, \quad$ thitung $>\mathrm{t}$ tabel, maka $\mathrm{H}_{\mathrm{a}}$ diterima dan $\mathrm{H}_{\mathrm{o}}$ ditolak. Dengan demikian disimpulkan bahwa secara parsial kemudahan perhitungan berpengaruh terhadap efisiensi pemrosesan data perpajakan pada pengusaha kena di Kota Tomohon.

Kemudahan pelaporan mempunyai nilai signifkasi 0,260 yang berarti nilai ini lebih besar dari 0.05 dengan $\mathrm{t}$ hitung $1.137<2.000$, t hitung $<\mathrm{t}$ tabel, maka $\mathrm{H}_{\mathrm{a}}$ ditolak dan $\mathrm{H}_{\mathrm{o}}$ diterima. Dengan demikian disimpulkan bahwa secara parsial kemudahan pelaporan tidak berpengaruh terhadap efisiensi pemrosesan data perpajakan pada pengusaha kena di Kota Tomohon.

Keandalan e-SPT mempunyai nilai signifkasi 0,782 yang berarti nilai ini lebih besar dari 0.05 dengan $\mathrm{t}$ hitung $0.278<2.000$, t hitung $<\mathrm{t}$ tabel, maka $\mathrm{H}_{\mathrm{a}}$ ditolak dan $\mathrm{H}_{\mathrm{o}}$ diterima. Dengan demikian disimpulkan bahwa secara parsial keandalan e-SPT tidak berpengaruh terhadap efisiensi pemrosesan data perpajakan pada pengusaha kena di Kota Tomohon

Uji F digunakan untuk menguji pengaruh variabel kepraktisan, kemudahan perhitungan, kemudahan pelaporan dan keandalan e-SPT terhadap efisiensi pemrosesan data perpajakan pada pengusaha kena di Kota Tomohon secara bersama- sama. Berdasarkan hasil analisis diperoleh $\mathrm{F}$ hitung sebesar 68.779 dengan tingkat signifikansi 0.000 , yang jauh lebih kecil dari 0.05 , maka $\mathrm{H}_{\mathrm{a}}$ diterima dan $\mathrm{H}_{\mathrm{o}}$ ditolak, dengan demikian kepraktisan, kemudahan perhitungan, kemudahan pelaporan dan keandalan e-SPT berpengaruh secara simultan atau bersama-sama terhadap efisiensi pemrosesan data perpajakan pada pengusaha kena di Kota Tomohon.

Angka R sebesar 0.913 menunjukan bahwa korelasi atau hubungan variabel dependen dengan variabel independen cukup kuat yaitu sebesar 91.3\%, sedangkan nilai R Square atau koefisien determinasi adalah 0.833, nilai ini mengindikasikan bahwa $83.3 \%$ variasi atau perubahan dalam variabel dependen dapat dijelaskan oleh variasi atau perubahan variabel dependen. Sedangkan sisanya $16.7 \%$ dijelaskan oleh sebab - sebab lain yang tidak dimasukan dalam model penelitian. 


\section{Pembahasan}

Berdasarkan hasil uji t yang dilakukan untuk melihat pengaruh kepraktisan terhadap efisiensi pemrosesan data perpajakan pada pengusaha kena di Kota Tomohon diketahui bahwa nilai thitung kepraktisan mempunyai nilai signifkasi 0.007 yang berarti nilai ini lebih kecil dari 0.05 , dengan t hitung $2.824>2.000$ tabel, berdasarkan hal tersebut disimpulkan bahwa secara parsial kepraktisan berpengaruh terhadap efisiensi pemrosesan data perpajakan pada pengusaha kena di Kota Tomohon.

Hasil uji t yang dilakukan untuk melihat pengaruh kemudahan perhitungan terhadap efisiensi pemrosesan data perpajakan pada pengusaha kena di Kota Tomohon diketahui bahwa nilai thitung kemudahan perhitungan mempunyai nilai signifkasi 0.001 yang berarti nilai ini lebih kecil dari 0.05 , dengan $\mathrm{t}$ hitung 3.683 $>2.000$ tabel, berdasarkan hal tersebut disimpulkan bahwa secara parsial kemudahan perhitungan berpengaruh terhadap efisiensi pemrosesan data perpajakan pada pengusaha kena di Kota Tomohon.

Hasil uji t yang dilakukan untuk melihat pengaruh kemudahan pelaporan terhadap efisiensi pemrosesan data perpajakan pada pengusaha kena di Kota Tomohon diketahui bahwa nilai $\mathrm{t}_{\text {hitungkemudahan pelaporan }}$ mempunyai nilai signifkasi 0.260 yang berarti nilai ini lebih besar dari 0.05 , dengan t hitung $1.137<2.000$ tabel, berdasarkan hal tersebut disimpulkan bahwa secara parsial kemudahan pelaporan tidak berpengaruh terhadap efisiensi pemrosesan data perpajakan pada pengusaha kena di Kota Tomohon.

Hasil uji t yang dilakukan untuk melihat pengaruh keandalan e-SPT terhadap efisiensi pemrosesan data

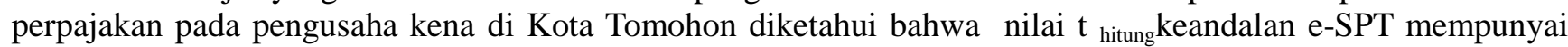
nilai signifkasi 0.782 yang berarti nilai ini lebih besar dari 0.05 , dengan $t$ hitung $0.278<2.000$ tabel, berdasarkan hal tersebut disimpulkan bahwa secara parsial keandalan e-SPT tidak berpengaruh terhadap efisiensi pemrosesan data perpajakan pada pengusaha kena di Kota Tomohon.

Pajak menjadi tulang punggung pendapatan Negara dalam pembiayaan dan pembangunan kehidupan bangsa ini.Pajak bersifat dinamis dan mengikuti perkembangan kehidupan sosial dan ekonomi masyarakat. Tuntutan akan peningkatan penerimaan, penyesuaian struktur perpajakan serta stabilisasi dan penyehatan ekonomi dan adanya ketidakpuasan dari masyarakat atas layanan perpajakan yang diberikan selama ini. Oleh karena itu untuk memperbaiki diri dan meningkatkan pelayanan kepada masyarakat, Direktorat Jenderal Pajak melakukan modernisasi perpajakan yang meliputi reformasi kebijakan, reformasi administrasi dan reformasi pengawasan, hal ini didukung oleh perkembangan teknologi yang sudah sedemikian canggih.

Agar target penerimaan pajak tercapai harus didukung oleh fasilitas-fasilitas pajak dan kepatuhan wajib pajak dalam membayar kewajibannya. Salah satu fasilitas pajak dalam rangka modernisasi administrasi perpajakan adalah elektronik SPT (e-SPT) merupakan aplikasi (software) yang dibuat oleh Direktorat Jenderal Pajak untuk digunakan oleh Wajib Pajak untuk kemudahan dalam menyampaikan SPT. Dimana aplikasi e-SPT memiliki tujuan sebagai berikut:

1. Data-data perpajakandapatterorganisasidenganbaikdansistematis.

2. Mempermudahdalammenghitung SPT dan pembuatanlaporanperpajakan.

3. Mudahdanefisiendalampelaporanperpajakan.

Tetapi aplikasi e-SPT ini juga memiliki hambatan-hambatan dalam pelaksanaannya, antara lain:

1. Kurangmampudalammelakukansinkronisasi format data dengan format data yang diinginkanolehsistem ASP (Application Services Provider) dansistem DJP (DirektoratJenderalPajak).

2. Tidakadanyalayanantambahanuntukmengkonversi data yang diperlukanolehWajibPajak.

3. Pelaksanaansosialisasimengenaie-SPT tidakmerata, sehinggakurangnyainformasimengenaikegunaandancaramenggunakanaplikasi e-SPT.

4. Saranadanprasarana yang belummemadaidari DJP.

5. Masihrendahnyakemampuansumberdayamanusia DJP dalampengoperasiansistem e-SPT.

Adalah penting untuk mengetahui bagaimana persepsi para Wajib Pajak mengenai peningkatan kinerja Direktorat Jenderal Pajak khususnya dalam hal pemrosesan data perpajakan dengan diterapkannya sistem SPT digital karena secara tidak langsung, hal ini berkaitan dengan kepercayaan dan dukungan masyarakat terhadap niat baik pemerintah untuk menyelenggarakan penghimpunan dan pemanfaatan dana hasil pajak secara jujur, transparan dan adil. Jika menurut persepsi para Wajib Pajak penerapan e-SPT selama ini bermanfaat dalam proses pengisian SPT maka penerapan e-SPT berpengaruh secara signifikan terhadap efisiensi pengisian SPT sehingga pengisian SPT menjadi efisien.

Penelitian ini di dukung oleh penelitian terdahulu Salim, Puspa dan Darmayanti (2013)menelititentangFaktor-Faktor yang Mempengaruhi Penggunaan Fasilitas e-Filling oleh Wajib Pajak Sebagai Sarana Penyampaian SPT Masa Secara Online dan Realtime.(Studi empiris Pada Wajib Pajak Badan di 
KPP Madya Jakarta Pusat). Kesimpulandaripenelitiantersebutadalahfaktor-faktor yang mempengaruhi intensitas perilaku dalam penggunaan $e$-filling sebagai saranapelaporan pajak secara online dan realtimepada KPP Madya Jakarta Pusat adalahpersepsi kemudahan, keamanan dankerahasiaan data.Persamaandenganpenelitianpenulisadalahalatanalisissedangkanperbedaanyaterletakpada penempatan variabel independen dan dependen.

\section{Kesimpulan}

\section{PENUTUP}

Kesimpulandalampenelitianiniadalah

1. Hasil analisis menunjukan bahwa kepraktisan, kemudahan perhitungan, kemudahan pelaporan dan keandalan e-SPTsecara bersama-sama berpengaruh terhadap efisiensi pemrosesan data perpajakan pada pengusaha kena pajak di Kota Tomohon.

2. Kepraktisan berpengaruh secara signifikan terhadap efisiensi pemrosesan data perpajakan pada pengusaha kena pajak di Kota Tomohon.

3. Kemudahan perhitungan berpengaruh secara signifikan terhadapefisiensi pemrosesan data perpajakan pada pengusaha kena pajak di Kota Tomohon.

4 Kemudahan pelaporan tidak berpengaruh secara signifikan terhadapefisiensi pemrosesan data perpajakan pada pengusaha kena pajak di Kota Tomohon.

5 Kepraktisan e-SPT tidak berpengaruh secara signifikan terhadapefisiensi pemrosesan data perpajakan pada pengusaha kena pajak di Kota Tomohon.

\section{Saran}

Saran dalam penelitian ini sebagai berikut :

1. Kantor Pajak Pratama Kota Tomohon agar supaya terus melakukan sosialisasi berupa penjelasan kepada seluruh masyarakat yang menjadi Wajib Pajak akan pentingnya dan manfaat membayar pajak seperti penyuluhan serta memberikan training pengisian SPT dengan menggunakan media online yang diberikan secara berkesinambungan.

2. Aturan perpajakan mengenai Tata Cara Pelaporan dan Pengolahan Surat Pemberitahuan Tahunan perlu diperbaiki, dibuat semudah mungkin dan tidak rumit, sehingga WP mau menggunakan sistem e-filing untuk melakukan pelaporan SPT Tahunan Wajib Pajak

\section{DAFTAR PUSTAKA}

Bohari, 2006. Pengantar Hukum Pajak, Penerbi PT. Raja Gravindo Persada, Jakarta.

Lingga, Ita Salsalina 2012.Pengaruh Penerapan e-SPT Terhadap Efisiensi Pemrosesan Data Perpajakan: Survey Terhadap Pengusaha Kena Pajak pada KPP Pratama X, Bandung. Jurnal Akuntansi Vol.4 No.2 hal 101114Diakses 27 November 2014

Kuncoro, Mudrajad 2006. Metode Riset untuk Bisnis dan Ekonomi. FE Universitas Gadjah Mada Penerbit Erlangga, Jogyakarta.

Lubis, Irsan, 2010. Akuntansi Perpajakan. LPMB/STEI, Ciledu

Salim Emil, Dwi Fitri Puspa dan Yeasy Darmayanti 2013 Faktor-Faktor yang Mempengaruhi Penggunaan Fasilitas e-Filling oleh Wajib Pajak Sebagai Sarana Penyampaian SPT Masa Secara Online dan Realtime.(Studi empiris Pada Wajib Pajak Badan di KPP Madya Jakarta Pusat). www/hhttp/ jurnal akuntansipajak.ac.id. 2 hal315-345 Diakses 27 November 2014

Simamora Hendry 2013. Akuntansi Pajak. Stard Date Publiser, Jakarta.

Undang-Undang Nomor 16 tahun 2000 mengenai Ketentuan Umum dan Tata Cara Perpajakan.

Undang-Undang Nomor 16 tahun 2009 mengenai Ketentuan Perpajakan. 
Tamboto, Falerian R.A 2013 Pengaruh Penerapan e-SPT PPN Terhadap Efisiensi Pengisian SPT PPN Menurut Persepsi Pengusaha Kena Pajak pada KPP Pratama ManadoJurnal EMBA 2059 Vol.1 No.4 Desember 2013, Hal. 2059-2068. Diakses 27 November 2014. 